\title{
T-cell responses to human papillomavirus type 16 among women with different grades of cervical neoplasia
}

\author{
JC Steele*,', CH Mann², S Rookes', T Rollason ${ }^{3}$, D Murphy ${ }^{4}$, MG Freeth ${ }^{5}$, PH Gallimore' and S Roberts' \\ 'Cancer Research UK Institute for Cancer Studies, University of Birmingham, Edgbaston, Birmingham BI5 2TT, UK; ${ }^{2}$ Department of Gynaecological \\ Oncology, Birmingham Women's Hospital, Edgbaston, Birmingham B 15 2TG, UK; ${ }^{3}$ Department of Pathology, Birmingham Women's Hospital, Edgbaston, \\ Birmingham BI5 2TG, UK; ${ }^{4}$ Department of Gynaecological Oncology, New Cross Hospital, Wolverhampton, West Midlands WVIO OQP, UK; \\ ${ }^{5}$ Department of Histopathology, New Cross Hospital, Wolverhampton, West Midlands WVIO OQP, UK
}

Infection with high-risk genital human papillomavirus (HPV) types is a major risk factor for the development of cervical intraepithelial neoplasia (CIN) and invasive cervical carcinoma. The design of effective immunotherapies requires a greater understanding of how HPV-specific T-cell responses are involved in disease clearance and/or progression. Here, we have investigated T-cell responses to five HPVI6 proteins (E6, E7, E4, LI and L2) in women with CIN or cervical carcinoma directly ex vivo. T-cell responses were observed in the majority (78\%) of samples. The frequency of CD4 + responders was far lower among those with progressive disease, indicating that the CD4 + T-cell response might be important in HPV clearance. CD8 + reactivity to E6 peptides was dominant across all disease grades, inferring that E6-specific CD8 + T cells are not vitally involved in disease clearance. T-cell responses were demonstrated in the majority (80\%) of cervical cancer patients, but are obviously ineffective. Our study reveals significant differences in HPVI 6 immunity during progressive CIN. We conclude that the HPV-specific CD4 + T-cell response should be an important consideration in immunotherapy design, which should aim to target preinvasive disease. British Journal of Cancer (2005) 93, 248-259. doi: I0.1038/sj.bjc.6602679 www.bjcancer.com

Published online 28 June 2005

(c) 2005 Cancer Research UK

Keywords: T cells; CIN; disease grade; HPVI6; ELISPOT

Cervical carcinoma is the second most common female cancer worldwide, with 400000 new cases diagnosed each year (Boyle, 1997; Landis et al, 1998). Infection by human papillomavirus (HPV) is a major risk factor for the development of invasive cervical carcinoma and its precursor cervical intraepithelial neoplasia (CIN). Nearly all (99.7\%) cervical cancers are positive for HPV DNA, with HPV type 16 (HPV16) being the most prevalent and present in up to $70 \%$ of cervical cancers regardless of geographical origin (Bosch et al, 1995; Walboomers et al, 1999).

It is clear that there are effective host defence mechanisms against HPVs. Genital infection with HPV is generally transient, with the majority of individuals showing clearance of the virus within 1 year of detection (Evander et al, 1995; Ho et al, 1998; Woodman et al, 2001; Sellors et al, 2003). In fact, only a minority of women develop persistent infections with focally high levels of HPV DNA, and only some of these progress to high-grade disease and invasive carcinoma (Herrero et al, 2000). Cell-mediated immunity is believed to be critical in the resolution and control of HPV. HIV-infected patients show multiple recurrences of cervical HPV infections (Fruchter et al, 1998) and an increased incidence of genital warts (Fennema et al, 1995) that appear to reflect an increased risk of progression from subclinical to clinical infection (Chirgwin et al, 1995).

*Correspondence: Dr JC Steele; E-mail: j.c.steele@bham.ac.uk Received 9 March 2005; revised 17 May 2005; accepted 31 May 2005; published online 28 June 2005
There are several studies providing information about CD4 $+\mathrm{T}$ cell responses to HPV16. Using either fusion proteins, panels of overlapping peptides, or virus-like particles (VLPs), CD4 responses to HPV16 E6 (Cubie et al, 1989; Strang et al, 1990; Nakagawa et al, 1996; Tsukui et al, 1996; Kadish et al, 1997, 2002; Welters et al, 2003; de Jong et al, 2004), E7 (Cubie et al, 1989; Strang et al, 1990; Altmann et al, 1992; Kadish et al, 1994, 1997, 2002; de Gruijl et al, 1996a,b, 1998; Luxton et al, 1996; Nakagawa et al, 1996; Tsukui et al, 1996; Hopfl et al, 2000; van der Burg et al, 2001; Welters et al, 2003), E2 (Bontkes et al, 1999; de Jong et al, 2002, 2004; Welters et al, 2003), E5 (Gill et al, 1998), E4 (Cubie et al, 1989; Nakagawa et $a l, 1996$ ) and L1 (Strang et al, 1990; Nakagawa et al, 1996; Shepherd et al, 1996; Luxton et al, 1997; de Gruijl et al, 1999) have been demonstrated in both patient and healthy control populations. No clear pattern has yet emerged as to which of these responses, if any, might be associated with regression or progression of disease as only a limited number of prospective studies have been carried out.

The role of naturally occurring cytotoxic $\mathrm{T}$ cells (CTLs) in mediating regression of HPV-related disease has not been proven. Using a variety of restimulation protocols, HPV16 E2-, E6- and E7specific CTLs can be detected in patients with previous (Nakagawa et al, 1997) or ongoing HPV infections (Alexander et al, 1996; Borysiewicz et al, 1996; Evans et al, 1996, 1997; Ressing et al, 1996; Jochmus et al, 1997; Konya et al, 1997; Nimako et al, 1997). Most of this work has involved the use of selected peptides bound to the surface of various target cells to restimulate CD8 responses in 
vitro. As such, these experiments are restricted to only a few HLA alleles using peptides that may not be representative of HPV epitopes expressed during natural infection. Studies using whole HPV proteins to restimulate CTL responses, either in a soluble form (Nakagawa et al, 1997) or expressed by recombinant viral vectors (Nimako et al, 1997), where the whole protein is naturally processed, have been more successful. Autologous dendritic cells (DCs) presenting HPV16 peptides or whole proteins have also been used to restimulate E6- and E7-specific CTL responses from both normal donors and women with cervical carcinoma in vitro (Murakami et al, 1999; Schoell et al, 1999; Thornberg et al, 2000; Davidson et al, 2001; Liu et al, 2001; Chiriva-Internati et al, 2002; Valdespino et al, 2005), although it is not clear whether these represent primary or memory T-cell responses. Overall, the results suggest that naturally occurring HPV E6- and E7-specific CTLs do exist in patients with HPV-associated disease, although their detection may depend on the methods used to reactivate them in vitro. More recently, using tetramer technology, it has been shown directly that HPV16 E7-specific CTLs do exist in the peripheral blood of women with high-grade CIN and cervical carcinoma, but they are extremely rare (Youde et al, 2000). Very little is known about the HPV16-specific CTL response to proteins other than E6 and E7.

The link between HPV16 and cervical carcinoma opens up the possibility of immune $\mathrm{T}$-cell intervention, either against the preinvasive lesions from which tumours arise, or against the virus antigen-positive tumour cells themselves. To effect such strategies will require a better understanding of the spectrum of T-cell responses induced by HPV16 antigens during the course of natural infection, and of their role in disease clearance and/or progression. Much of the work to date has understandably focused on responses to the E6 and E7 transforming proteins, since these are the only viral antigens constitutively expressed in HPV-positive tumour cells. By contrast, there has been no concerted effort to look at the totality of responses to a single agent, including responses to viral antigens that are expressed later in the replication cycle that may be useful targets for the treatment of preinvasive lesions. In this study, we have used CD4- and CD8-depleted populations of responder cells in an ELISPOT assay of IFN- $\gamma$ release to screen directly ex vivo for both $\mathrm{CD} 4+$ and $\mathrm{CD} 8+\mathrm{T}$-cell responses to five HPV16 proteins (E6, E7, E4, L1 and L2) from a cohort of 41 women with varying grades of cervical disease. The frequency, magnitude and antigen specificity of the responses obtained are discussed in relation to disease severity.

\section{MATERIALS AND METHODS}

\section{Patients and controls}

A total of 41 women attending colposcopy clinics or undergoing surgery for cervical disease (Department of Gynaecological Oncology, Birmingham Women's Hospital, Birmingham, UK) were investigated. Ethical approval for this study was obtained from the South Birmingham Research Ethics Committee (Study Number 5147) and informed consent was obtained from all subjects. Abnormal cervical cytology was diagnosed and confirmed by histopathology. Patients were assigned to one of four groups according to the histology reports obtained from cervical tissue taken at the time they were bled: those reported to have no evidence of CIN, those with low-grade disease (CIN I), high-grade disease (CIN II/III) and those with cervical carcinoma. The clinical details are shown in Table 1.

The HPV genotype of patient biopsies obtained during the course of this study could not be established. However, the transient nature of genital HPV infections questions the validity of HPV typing at a single time point, since this may not necessarily reflect a past history of HPV infection in a significant proportion of women, especially those with low-grade disease (Woodman et al, 2001). High-grade disease would be expected to be associated with a more persistent HPV infection.

Nine age-matched female virgins were recruited as negative controls. Virginity was established by gynaecologists who obtained full clinical and sexual histories. Normal healthy donors were considered not suitable as a negative control group, since the evidence suggests that a significant number will have encountered this virus (Woodman et al, 2001). Indeed, many recent studies have demonstrated HPV16-specific T-cell responses in normal donors (de Jong et al, 2002, 2004; Welters et al, 2003) and HPV16

Table I Clinical details

Disease grade

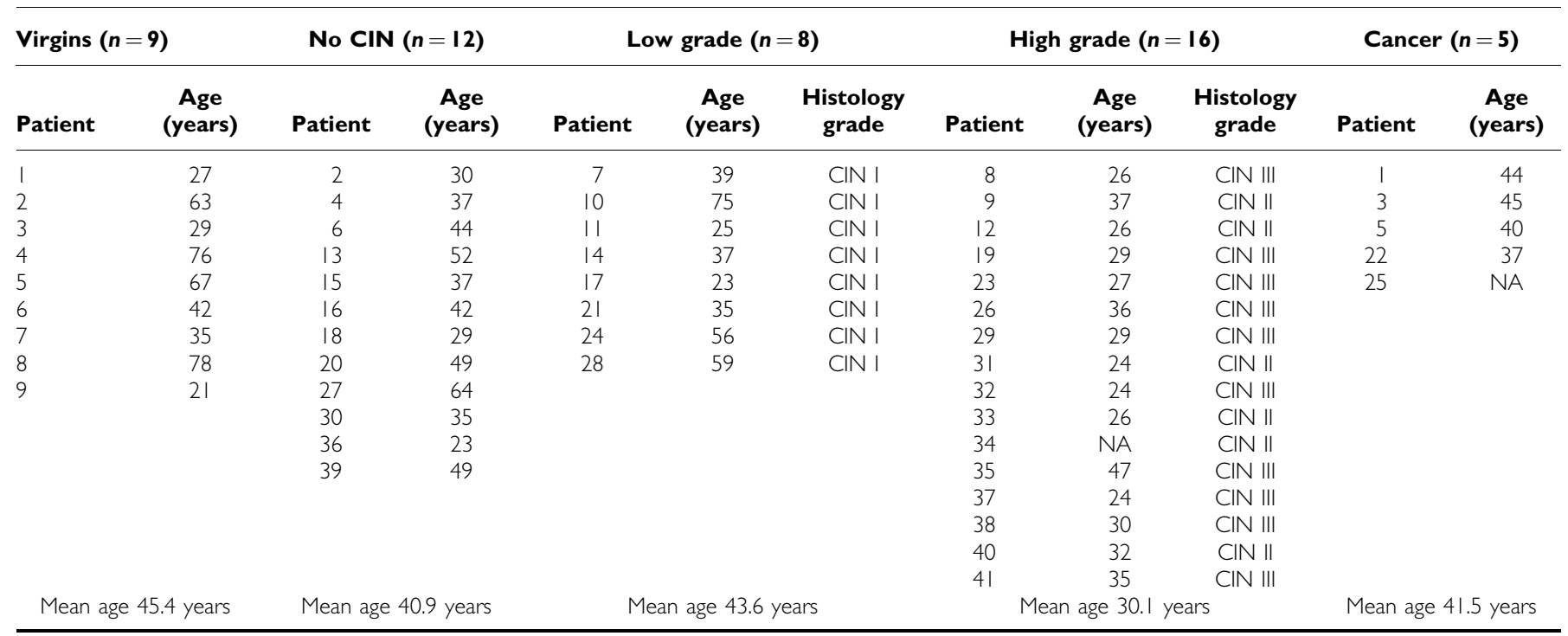

Details of the virgins $(I-9)$ and patients $(I-4 \mid)$ involved in the study, including their age at the time of sampling, and, for the patients, the grade of cervical neoplasia reported following histological analysis of cervical tissue obtained at the same time. NA, not available. 
is common in women with normal cytology (Bosch et al, 1995). Therefore, virgins are the control group most likely to represent HPV16 negativity, although it is not possible to establish whether this is true in every case.

\section{Preparation of CD4-enriched and -enriched T-cell populations}

Unfractionated mononuclear (UM) cells were separated from 40-60 $\mathrm{ml}$ heparinised blood samples by isopycnic centrifugation on lymphocyte separation medium (Lymphoprep; Nycomed, Oslo, Norway) and cryopreserved in liquid nitrogen. CD4 + and $\mathrm{CD} 8+\mathrm{T}$-cell depletions were carried out on UM cells using antibody-coated magnetic beads (Dynal, Oslo, Norway) according to the method previously described (Steele et al, 2002). Depleted populations were used directly as responder cells in the ELISPOT assay. FACS analysis using dual-labelled antihuman CD8:FITC/anti-CD4:RPE, or the isotype-matched negative control IgG1:FITC/IgG1:RPE (Serotec, UK) was carried out each time to verify the depletions, and in order to calculate the number of $\mathrm{T}$ cells of the relevant phenotype being added to each well.

\section{Preparation of HPV16 VLPs for use in the ELISPOT assays}

A recombinant baculovirus containing the HPV16 L1 and L2 genes was kindly provided by Professor M Stanley (Department of Pathology, University of Cambridge). HPV16 VLPs were produced following the infection of SF9 insect cells, and were purified on caesium chloride gradients according to published methods (Cubie et al, 1998).

\section{ELISPOT assay of IFN $-\gamma$ release}

Overlapping synthetic peptides (30-35mers; Alta Bioscience, Birmingham, UK) covering the entire primary sequences of the HPV16 E6, E7 and E4 proteins (overlapping by $14-16$ amino acids; sequences shown in Table 2), and baculovirus-expressed HPV16 VLPs comprising both L1 and L2 were used to screen for CD4+

Table 2 Sequences of the 30-35mer peptides (overlapping by $14-16$ amino acids) covering HPVI6 E6, E7 and E4 proteins used to screen for CD4+ and CD8+ T-cell responses in ELISPOT assays of IFN- $\gamma$ release

aa

HPVI6 E6 sequences

MHQKRTAMFQDPQERPRKLPQLCTELQTTIHDI

KLPQLCTELOTTIHDIILECVYCKQOLLRREV

ECVYCKQQLLRREVYDFAFRDLCIVYRDGNPYA

FRDLCIVYRDGNPYAVCDKCLKFYSKISEYRHY

KCLKFYSKISEYRHYCYSVYGTTLEQQYNKPLC

YGTTLEQOYNKPLCDLLIRCINCOKPLCPEEK

RCINCQKPLCPEEKQRHLDKKQRFHNIRGRWT

DKKQRFHNIRGRWTGRCMSCCRSSRTRRETQL

HPVI6 E7 sequences

MHGDTPTLHEYMLDLQPETTDLYCYEQLNDSS

TDLYCYEQLNDSSEEEDEIDGPAGQAEPDRAHYNIV

AGQAEPDRAHYNIVTFCCKCDSTLRLCVOSTHVDI

STLRLCVQSTHVDIRTLE DLLMGTLGIVCPICSQKP

$20-55$

$42-76$

$63-98$

HPVI6 E4 sequences

MADPAAATKYPLLKLLGSTWPTTPPRPIPKPSP

WPTTPPRPIPKPSPWAPKKHRRLSSDQDQSQTPET

RLSSDODQSOTPETPATPLSCCTETOWTVLQSSLHL

TETQWTVLQSSLHLTAHTKDGLTVIVTLHP and CD8 + T-cell responses using an ELISPOT assay of IFN- $\gamma$ release (ELISPOT assay for human interferon- $\gamma$; Mabtech, Sweden). The ELISPOT assay procedure has been published previously (Steele et al, 2002). Briefly, CD4- or CD8-enriched responder cell populations were used at $4 \times 10^{5}$ cells per well (in duplicate) and peptides were added to a final concentration of $10 \mu \mathrm{g} \mathrm{ml}^{-1}$. A negative control well with no peptide or VLP and a positive control well containing cells and $0.2 \%$ PHA-P (Difco Laboratories) instead of peptide were included for every sample. The plates were counted using an automated system (AID, Strasbourg, Germany) and background counts obtained in the absence of peptide or VLP were subtracted. An ELISPOT response among the patient group was only considered positive if the number of spots obtained fell above a negative cutoff value. These were calculated for every peptide and the VLP preparation, and taken as 2 standard deviations (s.d.) above the mean of the counts obtained using the negative control group comprising nine agematched female virgins.

\section{Enzyme-linked immunosorbent assay (ELISA) to determine HPV16 antibody levels}

Purified baculovirus-expressed HPV16 VLPs (a kind gift from Professor Martin Sapp, University of Mainz, Mainz, Germany) were used in an ELISA to determine HPV16-specific antibody levels in plasma samples obtained from each subject. This source of VLPs was unsuitable for use in the ELISPOT assay due to problems with toxicity. An ELISA method for detection of HPV1 VLP-specific antibodies has been published by us recently (Steele et al, 2002). The procedure used here for HPV16 VLPs was the same, except that a biotinylated second antibody and a peroxidaselabelled StreptABComplex (Dako) were employed to increase the sensitivity. Antibody levels were quantitated by relating the absorbancies to that obtained from the positive control, an antiHPV16 L1 antibody, (Camvir 1, Abcam, UK) run under standard conditions on every assay plate. The negative cutoff value was taken as two standard deviations above the mean of the absorbencies obtained using the virgin controls.

\section{RESULTS}

To define the frequency and spectrum of T-cell responses to HPV16, we used five HPV16 proteins as targets; E6 and E7 are the main transforming proteins and are expressed early in the infection cycle, E4 is an abundant protein that is expressed at an intermediate and late stage, and the capsid proteins L1 and L2 appear at later stages of the life cycle. Overlapping synthetic peptides covering the entire primary sequence of E6, E7 and E4 (30-35mers; sequences are shown in Table 2) were used in an ELISPOT assay of IFN- $\gamma$ release. It is important to note that similar-length peptides have been used successfully in other human immunological studies, including ELISPOT assays, to detect HPV-specific T-cell responses (van der Burg et al, 2001; de Jong et al, 2002, 2004; Welters et al, 2003). Human papillomavirus 16 VLPs were used as a source of L1 and L2 antigens in the ELISPOT assay.

\section{T-cell reactivity was detected in the majority of patients}

To determine whether responding IFN- $\gamma$-secreting $\mathrm{T}$ cells in the ELISPOT were CD8 + or CD4+, peripheral blood lymphocytes were negatively depleted using magnetic beads. FACS analysis of the CD4- or CD8-depleted T-cell populations revealed that in nearly all cases there was a depletion of greater than $99 \%$ of the appropriate T-cell subset (data not shown). The results of the ELISPOT assays are shown in Figure 1 and the data are summarised in Figure 2. We demonstrated either $\mathrm{CD} 4+$ or 
E6 Peptide 1. MHQKRTAMFQDPQERPRKLPQLCTELQTTIHDI (aa 1-33)
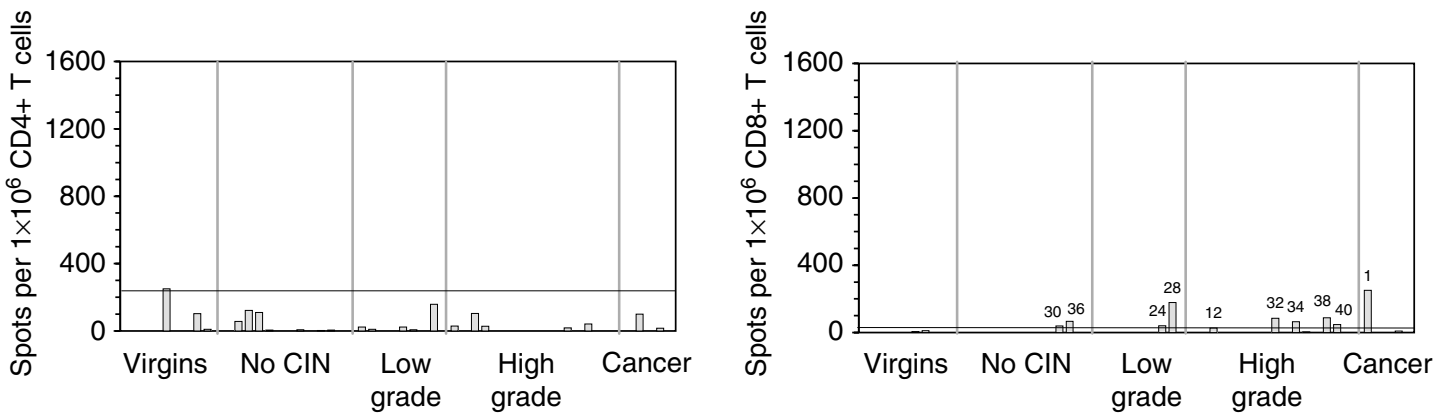

E6 Peptide 2. KLPQLCTELQTTIHDIILECVYCKQQLLRREV (aa 18-49)
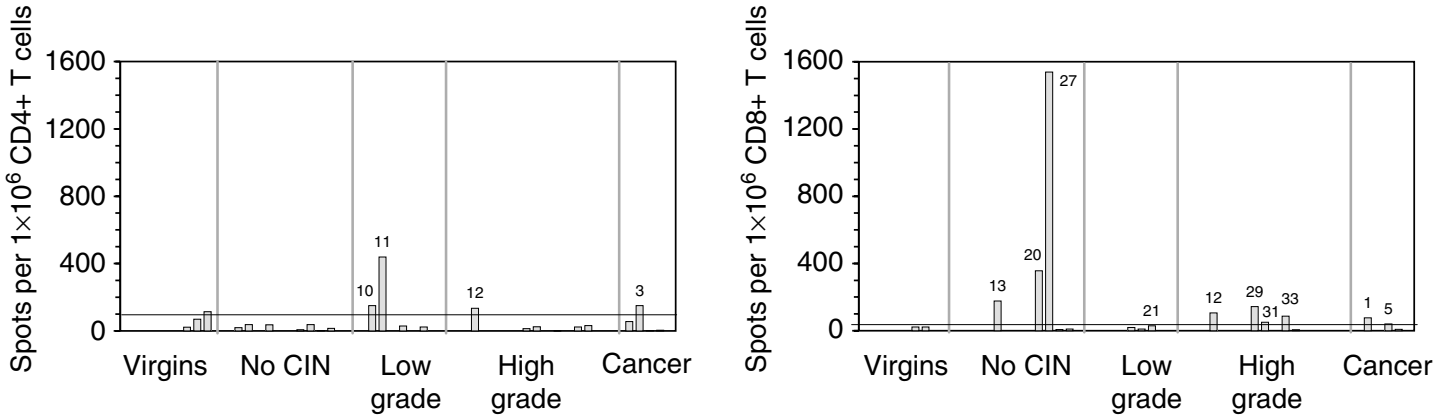

E6 Peptide 3. ECVYCKQQLLRREVYDFAFRDLCIVYRDGNPYA (aa 36-68)
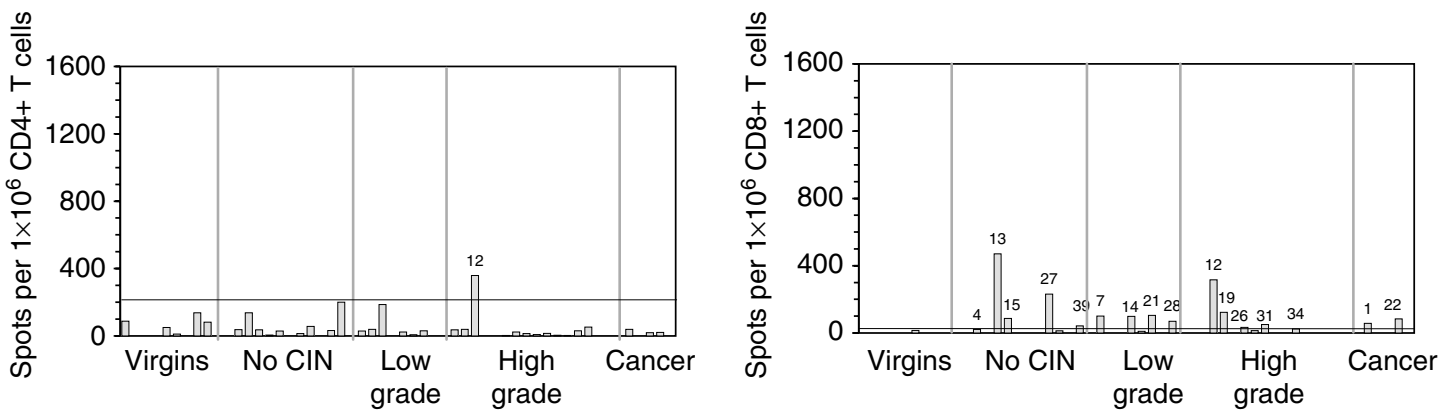

E6 Peptide 4. FRDLCIVYRDGNPYAVCDKCLKFYSKISEYRHY (aa 54-86)
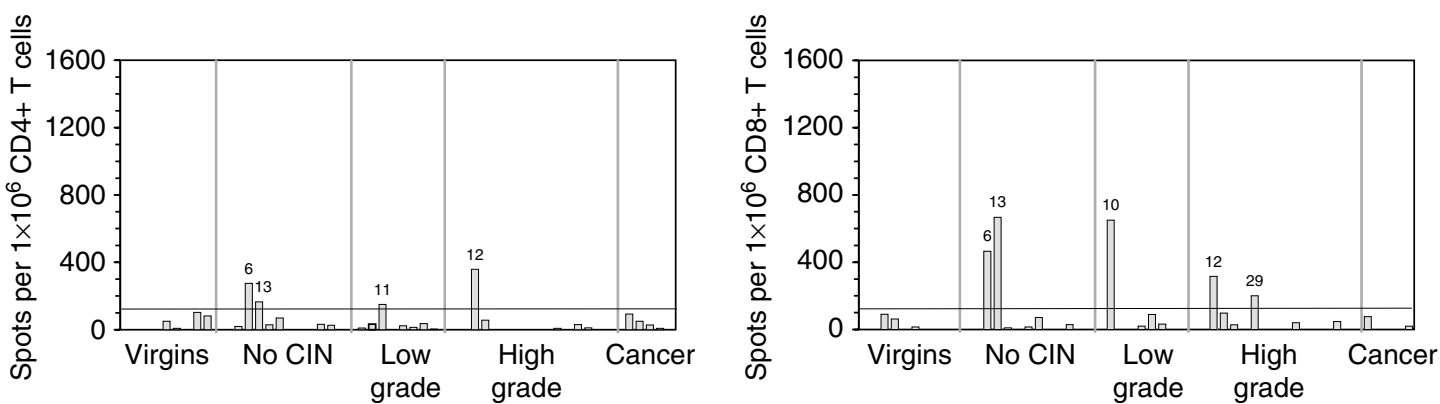

Figure I CD4 + (on the left side of the figure) and CD8 + (on the right side of the figure) T-cell reactivities to HPVI6 E6, E7, E4 peptides and HPVI6 virus-like particles. CD4 + and CD8 + enriched responder cell populations from each patient were screened against 30-35mer peptides (overlapping by 14- 16 amino acids) covering the entire primary sequences of the HPVI6 E6, E7 and E4 proteins (sequences shown using an ELISPOT assay of interferon- $\gamma$ release). The assay employed $4 \times 10^{5}$ responder cells well ${ }^{-1}$ (in duplicate), and both the peptides and the VLPs were used at a concentration of $10 \mu g \mathrm{ml}{ }^{-1}$. Responses obtained from the negative control group comprising nine age-matched female virgins were used to establish the negative cutoff values for each peptide and the VLPs (mean +2 s.d.). Positive responses are those which fall above the negative cutoff value $(-)$, and the patient number is indicated. Results are expressed as the number of spots obtained per $\mathrm{I} \times 10^{6} \mathrm{~T}$ cells of the appropriate phenotype added to each well. These figures were calculated following FACS analysis of depleted cell samples. Any background reactivity in the absence of peptide or VLPs has been subtracted. 

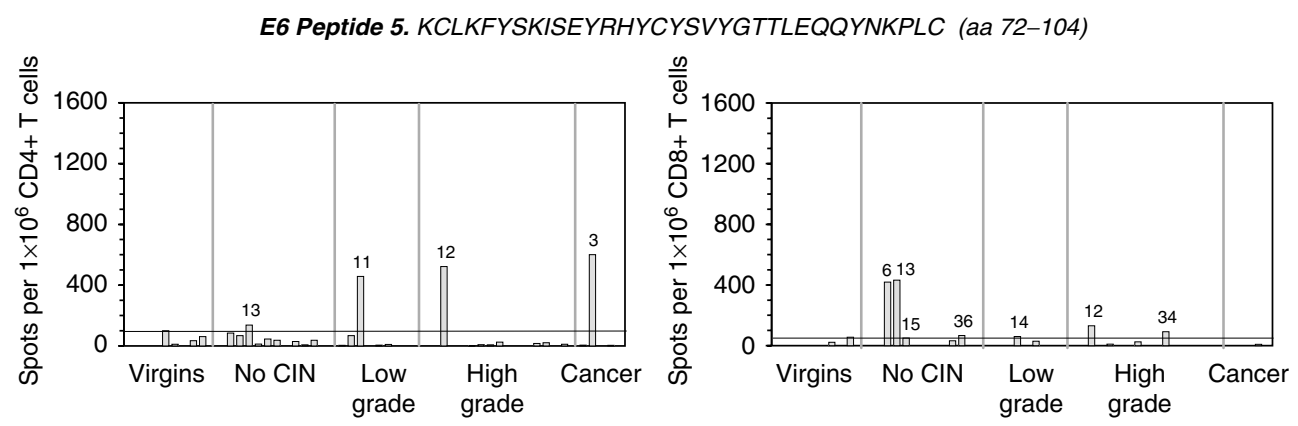

E6 Peptide 6. YGTTLEQQYNKPLCDLLIRCINCQKPLCPEEK (aa 91-122)
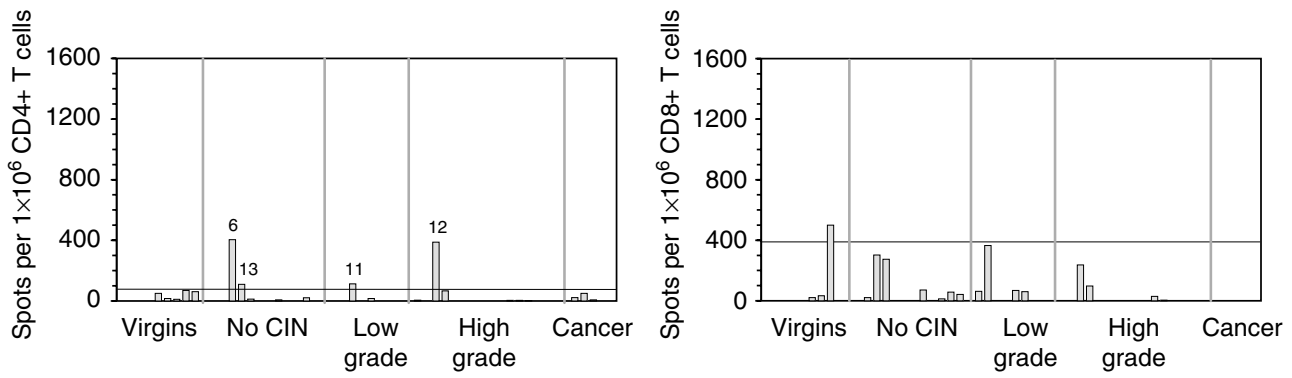

E6 Peptide 7. RCINCQKPLCPEEKQRHLDKKQRFHNIRGRWT (aa 109-140)
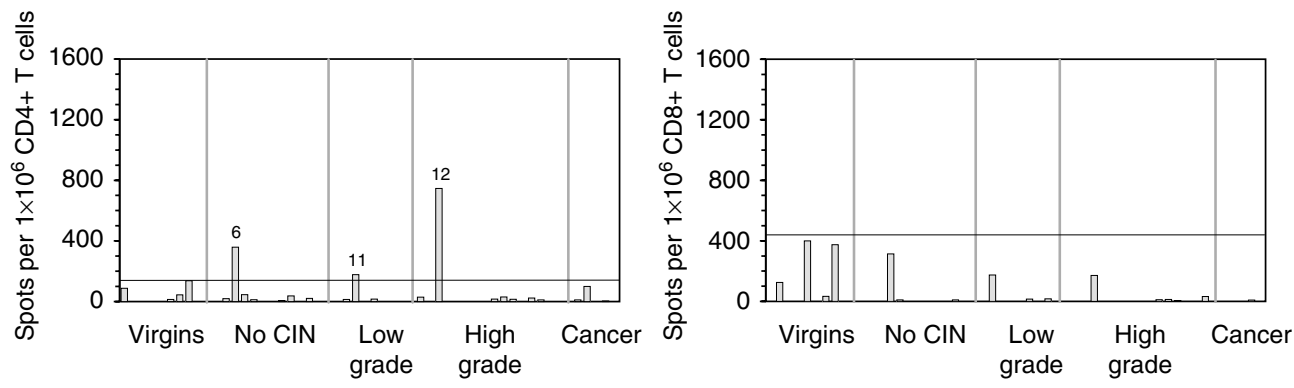

E6 Peptide 8. DKKQRFHNIRGRWTGRCMSCCRSSRTRRETQL (aa 127-158)
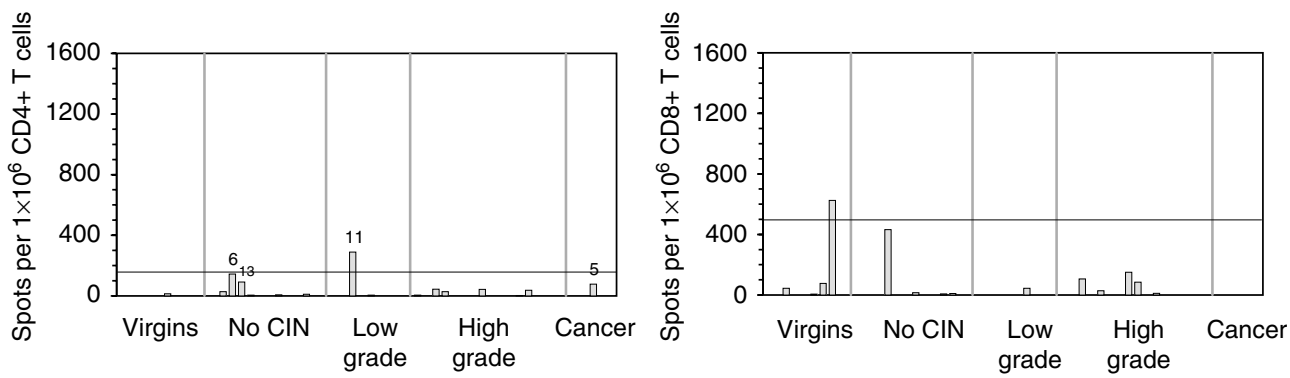

E7 Peptide 1. MHGDTPTLHEYMLDLQPETTDLYCYEQLNDSS (aa 1-33)
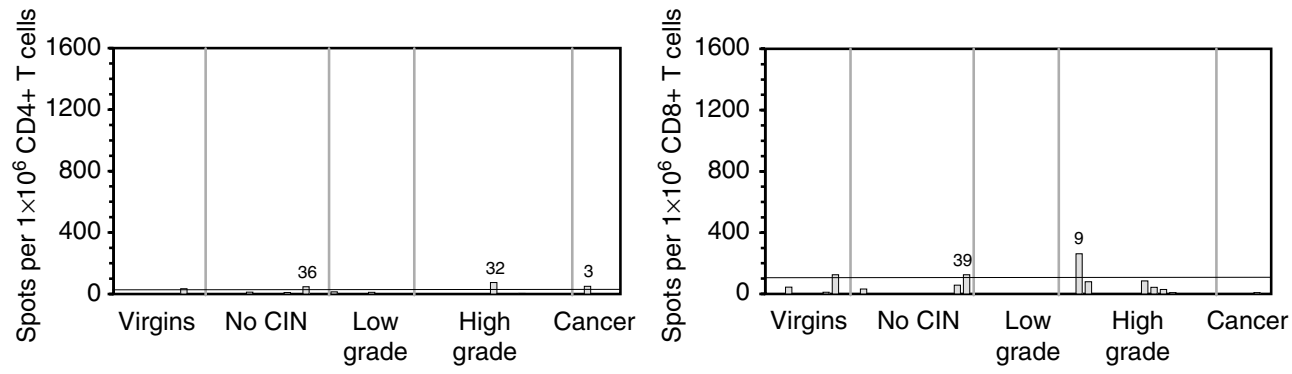

Figure I (Continued)

CD8 + T-cell reactivity in $78 \%$ (32 out of 41 ) of the patient samples tested, with $34 \%$ (14 out of 41 ) showing both CD4 and CD8 responses (Figure 2A). Among the various disease grades, the frequency of ELISPOT responders overall was: no CIN, 83\%; low-grade disease, $87.5 \%$; high-grade disease, $69 \%$; cervical cancer, $80 \%$ (Figure 2B)

The majority of the control samples showed little or no T-cell reactivity, with the exception of numbers 5 and 9, both of 
E7 Peptide 2. TDLYCYEQLNDSSEEEDEIDGPAGQAEPDRAHYNIV (aa 20-55)
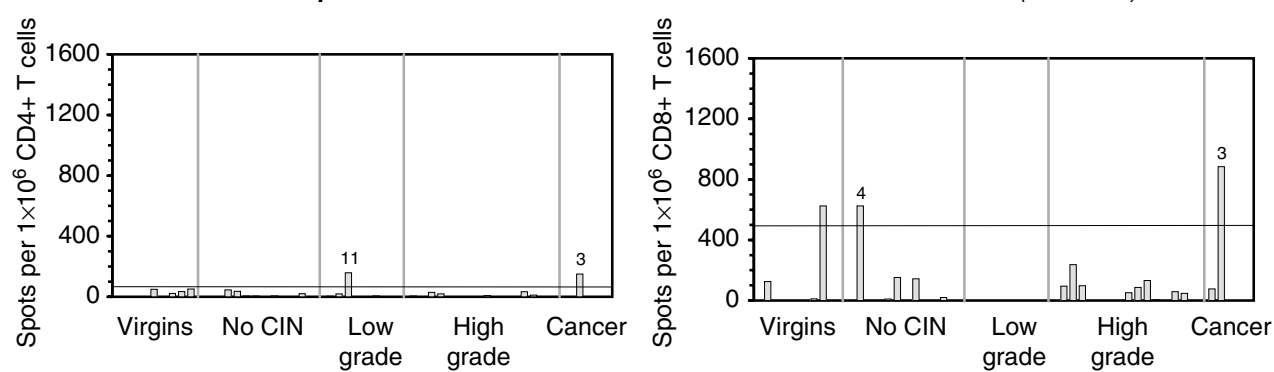

E7 Peptide 3. AGQAEPDRAHYNIVTFCCKCDSTLRLCVQSTHVDI (aa 42-76)
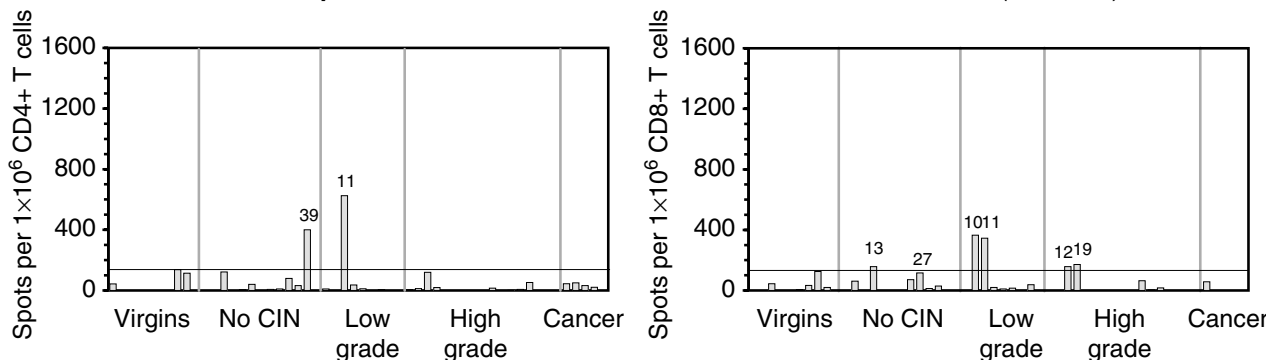

E7 Peptide 4. STLRLCVQSTHVDIRTLE DLLMGTLGIVCPICSQKP (aa 63-98)
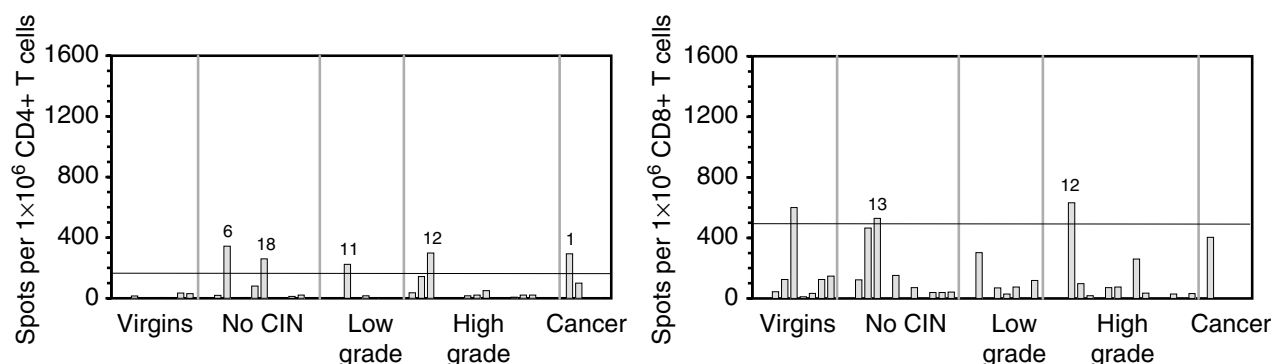

E4 Peptide 1. MADPAAATKYPLLKLLGSTWPTTPPRPIPKPSP (aa 1-33)
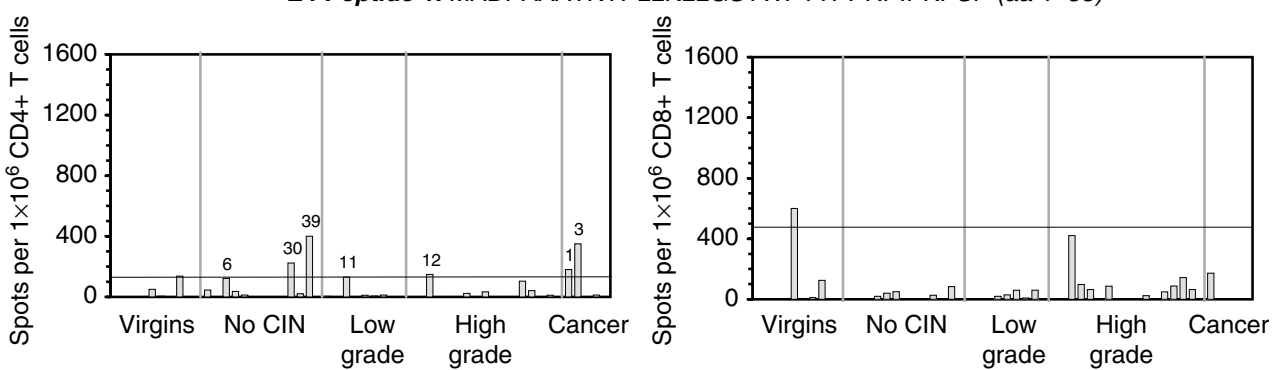

E4 Peptide 2. WPTTPPRPIPKPSPWAPKKHRRLSSDQDQSQTPET (aa 20-54)
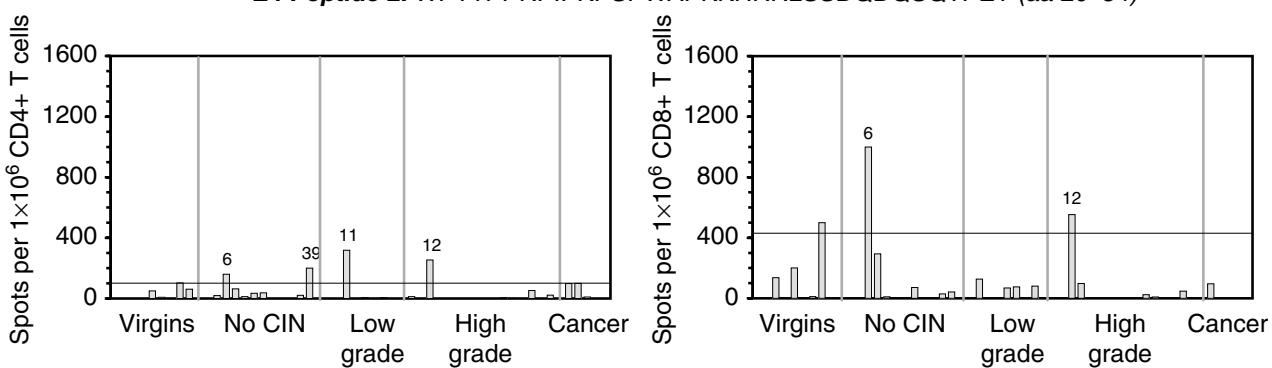

Figure I (Continued)

which demonstrated responses to a few peptides, particularly those covering HPV16 E6 (Figure 1). Although this increased the negative cutoff point quite considerably in some cases, it would be incorrect to eliminate these samples from the study.

\section{CD8 responses were observed more often than CD4 responses}

The results of the ELISPOT assays showed that CD8 + T-cell reactivity occurred at almost twice the frequency of $\mathrm{CD} 4+$ 

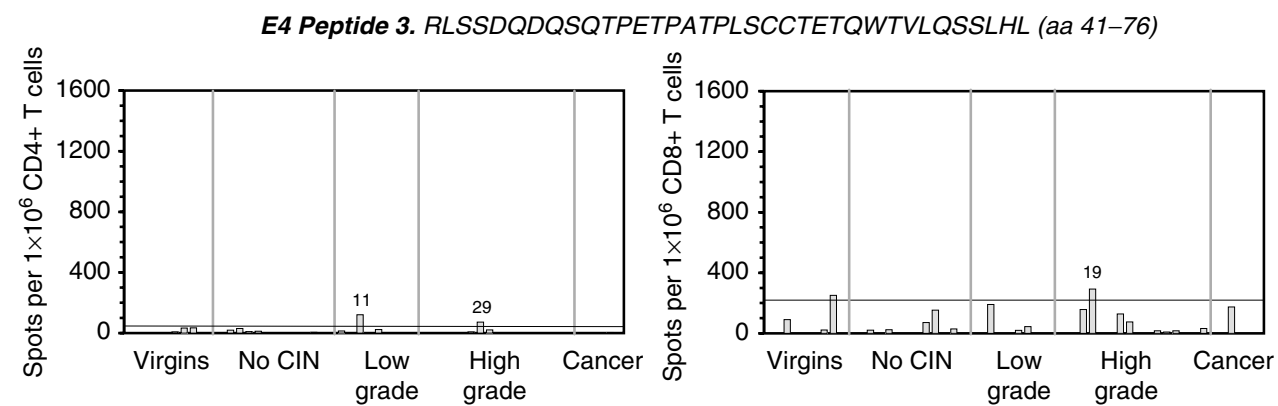

E4 Peptide 4. TETQWTVLQSSLHLTAHTKDGLTVIVTLHP (aa 63-92)
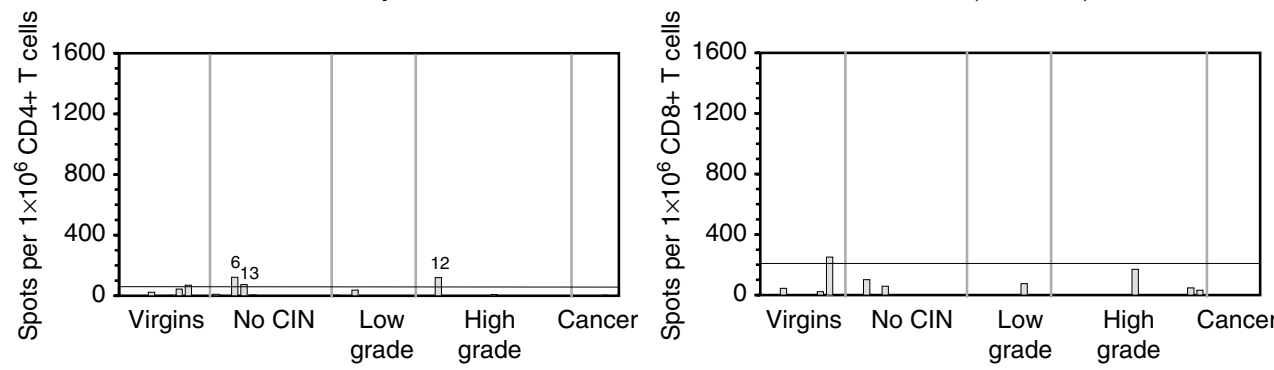

HPV16 Virus-like particles


Figure I (Continued)

reactivity (Figure 2A). CD4 responses were detected in 39\% (16 out of 41) of patients, and CD8 responses in $73 \%$ (30 out of 41 ). A similar percentage of women gave CD8 $+\mathrm{T}$-cell responses in each patient group: no CIN (75\%; nine out of 12), low-grade disease ( $75 \%$; six out of eight), high-grade disease $(69 \% ; 11$ out of 16$)$ and cervical cancer ( $80 \%$; four out of five) (Figure $2 \mathrm{C}$ ). In contrast, $\mathrm{CD} 4+$ responses were more frequent among the women with no CIN (50\%; six out of 12) or with cervical cancer (60\%; three out of five), than among those with low-grade (37.5\%; three out of eight) and high-grade disease (25\%; four out of 16 ) (Figure 2C). It is the decreased number of responders in these last two groups, particularly those with high-grade disease, which is responsible for our finding that $\mathrm{CD} 4+\mathrm{T}$-cell reactivity was much less common overall.

There was no significant difference in the magnitude of CD4 or CD8 responses obtained among patient groups (Figure 1). The greatest CD4 $+\mathrm{T}$-cell response (746 spots per $1 \times 10^{6} \mathrm{CD} 4+\mathrm{T}$ cells) was obtained from a woman with high-grade disease (patient 12), using an E6 peptide (RCINCQKPLCPEEKQRHLDKKQRFH NIRGRWT; aa 109-140). In a CD8 response, the highest frequency of spots (1538 spots per $1 \times 10^{6} \mathrm{CD} 8+\mathrm{T}$ cells) was obtained from a patient with no CIN (patient 27), again in response to an E6 peptide (KLPQLCTELQTTIHDIILECVYCKQQLLRREV; aa 18-49).

\section{CD8 T-cell responses to HPV16 E6 are dominant}

Differences in the antigen specificities of the CD4 and CD8 responses were also observed in the ELISPOT assays, although this was not related to disease grade (Figure 2D). A similar number of responses to E6 (50\%), E7 (56\%) and E4 (56\%) peptides was seen among the CD4-positive samples, but only $25 \%$ responded to VLPs. There was, however, a very dominant CD8 + T-cell response to peptides covering E6, with $93 \%$ of the CD8-positive samples showing reactivity to this protein. CD8 responses to the other proteins were far less common (E7 33\%; E4 10\%; VLP 7\%). For both $\mathrm{CD} 4+$ and $\mathrm{CD} 8+\mathrm{T}$-cell reactivity, many of the patients responded to more than one protein and saw more than one peptide on each (Figure 1). This was particularly noticeable with patients 6 and 13 (no CIN), 11 (low-grade disease) and 12 (highgrade disease).

\section{Seropositivity increases with disease severity and is related to positive T-cell reactivity}

The serological status of all subjects in the study was assessed in order to obtain additional information about HPV16 immune status. Antibodies to HPV16 VLPs were detected in 20 out of the 41 (48.7\%) plasma samples overall (Figure 3). In women with no CIN and low-grade disease, only 33 and $25 \%$ had positive serology, respectively. In contrast, higher frequencies of seropositivity were seen among the women with high-grade disease (69\%) and cervical cancer $(60 \%)$. The analysis revealed an increase in the frequency of antibody positivity (but not titre) with disease severity. The median antibody levels obtained were 0.04 (range: $0.025-0.52$ ) for the women with no CIN, 0.03 (range: $0-0.145$ ) for those with lowgrade disease, 0.0975 (range: $0-0.385$ ) for those with high-grade disease and 0.12 (range: $0.015-0.48$ ) for the cervical cancer patients. The differences in median values among the disease 
groups were not statistically significant $(P$-values all greater than 0.187; Mann-Whitney test). All of the patient groups had significantly higher titres than those obtained from the negative control group of female virgins ( $P$-values all less than 0.017; Mann - Whitney test), with the exception of those women with lowgrade disease $(P=0.091)$.

Out of the 20 seropositives obtained in this study, 18 (90\%) showed either $\mathrm{CD} 4+$ or $\mathrm{CD} 8+\mathrm{T}$-cell reactivity to HPV16 peptides in the ELISPOT assays. In all, 15 samples (71\%) out of the 21 with negative serology also gave a T-cell response. These samples were from patients who fell predominantly into the no $\mathrm{CIN}$ or low-grade disease groups. Interestingly, the patients who demonstrated $\mathrm{T}$-cell responses to multiple peptides and proteins (patients 6, 11, 12 and 13) (Figure 1) were seronegative, whereas the samples with the highest antibody titres (patients 5, 8, 18, 18 and 31) were either negative in the ELISPOT assay, or demonstrated $\mathrm{T}$-cell responses to only a narrow spectrum of peptides.

\section{DISCUSSION}

Using CD4- and CD8-enriched populations of responder cells isolated from 41 women with varying degrees of cervical disease (Table 1), we have investigated the frequency and spectrum of HPV16-specific CD4 + and CD8 + T-cell responses, using ELISPOT assays of IFN- $\gamma$ release, to HPV16 E4, E6, E7, L1 and L2. Significantly, in this study, cells were used directly ex vivo in the ELISPOT assay, without undergoing any kind of in vitro restimulation. We demonstrated either $\mathrm{CD} 4+$ or $\mathrm{CD} 8+\mathrm{T}$-cell reactivity in the majority of the patient samples tested (78\%), with $34 \%$ showing both CD4 and CD8 responses. There was little difference in the magnitude of the responses obtained between the CD4- or CD8-enriched populations (Figure 1), and among the various disease grades we found no significant difference in the frequency of ELISPOT responders overall (Figure 2B). The high detection rate of responses ex vivo was encouraging, considering the numerous reports suggesting that HPV-specific T cells are rare in peripheral blood. This is probably due to the high sensitivity of the ELISPOT assay, and the fact that the study was not restricted to selected peptides with specific HLA restrictions, that may lower the rate of detection.

\section{Human papillomavirus-specific CD4 $+\mathrm{T}$ cells may play a critical role in disease clearance}

An effective CTL response might be important for HPV clearance. Human papillomavirus 16-specific CTLs are more frequent in women with cleared infection than those with newly diagnosed Human papillomavirus 16-positive CIN (Nakagawa et al, 1997). However, both CD4 and CD8 effectors have been shown to be involved (Nakagawa et al, 2002). Our observation that the frequency of $\mathrm{CD} 4$ responders varies among the disease grades suggests that the $\mathrm{CD} 4+\mathrm{T}$-cell response might be critically involved in HPV clearance. The patients with low- and high-grade disease showed CD4 reactivity less frequently. These women are more likely to have progressive disease than those patients with no CIN, and it is possible that their lack of CD4 T-cell reactivity is contributing to progression. Notably, another study has used similar protocols to examine T-helper responses to HPV16 E2, E6 and E7 peptides in healthy individuals and in women with cervical carcinoma (Welters et al, 2003). CD4 reactivity was found to be far more common among the group of normal donors than the cancer patients, again suggesting that HPV16-specific CD4 + T-cell immunity is important for disease protection. Evidence from allograft recipients and HIV-infected individuals (Palefsky et al, 1999) also indicates that it is the absolute deficit in CD4 $+\mathrm{T}$ cells which is the important risk factor for HPV-induced disease and associated neoplastic progression in the immunocompromised individual, and CD4 $+\mathrm{T}$ cells have been shown to be prominent in resolving cutaneous (Iwatsuki et al, 1986) and genital warts (Coleman et al, 1994). Other recent studies looking for HPVspecific $\mathrm{T}$ cells in peripheral blood also suggest that helper $\mathrm{T}$ cells play a central role in the control of HPV infection, disease regression and clearance (Kadish et al, 2002; de Jong et al, 2004).

\section{Human papillomavirus-specific immunity is different in cancer}

We found the highest number of CD4 responders in the small group of patients with cancer. This is in agreement with some reports (de Gruijl et al, 1996a, b, 1998; de Jong et al, 2004), but not others, where CD4 responses have been found to be decreased in cancer (Luxton et al, 1996, 1997; Nakagawa et al, 1996; Hopfl et al, 2000; van der Burg et al, 2001; Welters et al, 2003). However, all of these studies use different methodologies and the majority used in vitro restimulation protocols. There seems to be little doubt that Tcell responses in patients clearing cervical HPV infection are different from those progressing to cervical cancer. It is conceivable that an ineffective HPV-specific CD4 + T-cell response early during infection will allow HPV to persist and the establishment of high-grade disease. However, it seems that the presence of a tumour will eventually induce CD4 $+\mathrm{T}$-cell immunity. This could be because the tumour will eventually breach the basement membrane of the epithelium and viral antigens will become exposed to the immune system. In invasive carcinoma, there will also be an increase in the amount of infected tissue and subsequently viral load. Indeed, HPV16 responses have been shown to be dependent on antigen dose in experiments using a murine model in which viral antigen is expressed in keratinocytes and mimics the natural route of infection (Chambers et al, 1994). A surprisingly high frequency of HPV-specific CD4+ $\mathrm{T}$-cell responses in women with cervical carcinoma compared to those with high-grade CIN has also been observed in a similar study published recently by de Jong et al (2004). They also looked at cytokine production and their results suggested that cervical cancers do not provide the appropriate proinflammatory environment for the induction of a potent and well-polarised T-cell response, and that if CD4 + T-cell priming occurs at this stage of disease it will most likely result in an ineffective antitumour response.

\section{CD8 + T-cell responses to HPV16 E6 are dominant}

Differences in the antigen specificities of the CD4 and CD8 responses were also observed in this study. There was a very dominant CD8 + T-cell response to peptides covering HPV16 E6 (Figure 1A), a protein known to be critical for malignant transformation and maintenance of the transformed phenotype. It could be concluded from our results that E6-specific CD8 + T cells do not play a major role in HPV clearance because they were so predominant across all disease grades (Figure 2C). This is supported by other studies where HPV16 E6-specific CTLs have been shown to be associated with disease and viral persistence (Bontkes et al, 2000; Nakagawa et al, 2000).

\section{Antigen specificity and disease severity are unrelated}

There was no obvious relationship between antigen specificity and disease severity for either CD4 + or CD8 + T-cell reactivities. This may be explained by the fact that the immune system is probably primed early on during productive infection when all of the HPV16 proteins are being expressed. Human papillomavirus 16 infection of the cervix is believed to become less productive as the disease progresses, and, following malignant transformation when HPV DNA becomes integrated in the host genome (Cullen et al, 1991), the expression of all viral proteins, other than E6 and E7, ceases. 

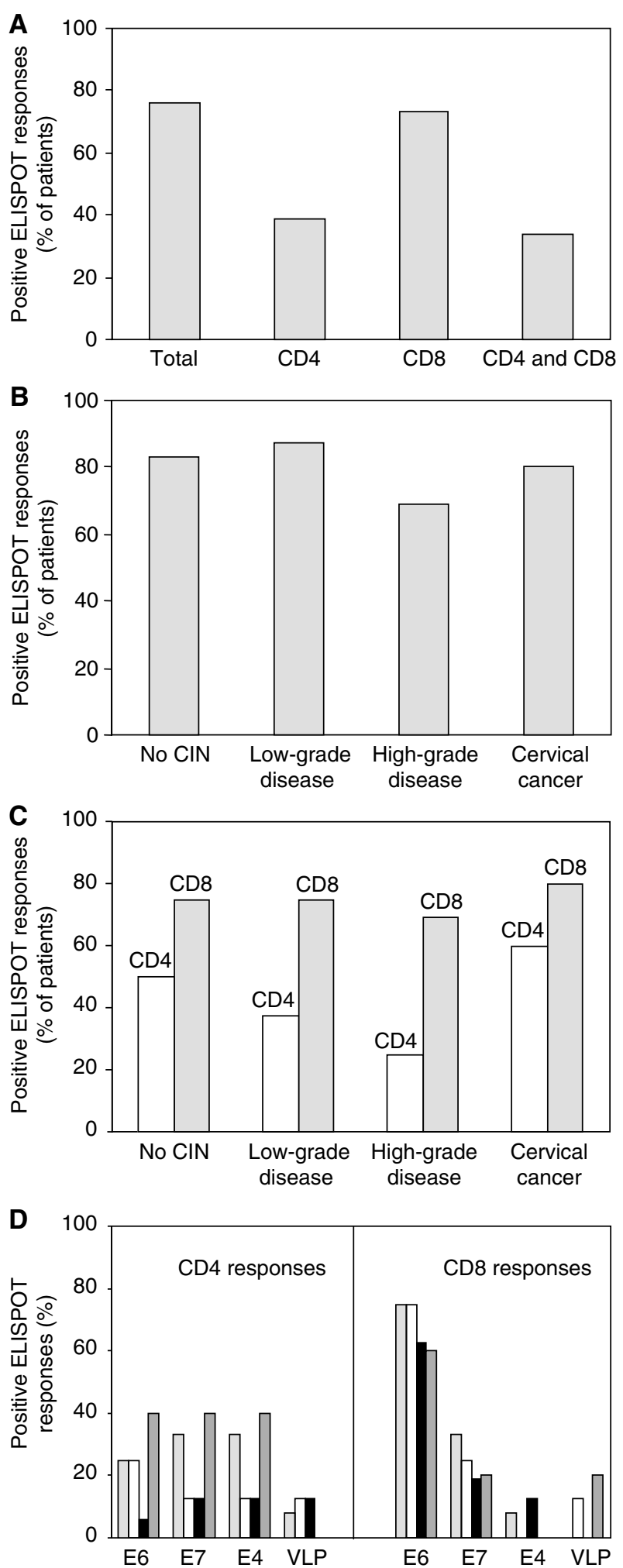

Figure 2 Summary of the ELISPOT assay data. The percentages of positive ELISPOT responses obtained generally $(\mathbf{A})$, in relation to disease grade (B), CD4 and CD8 responses in relation to disease grade $(\mathbf{C})$, and the antigen specificities of the CD4 + and CD8 + T-cell reactivities in relation to disease grade (D). $\square$ represents no $\mathrm{CIN}, \square$ low-grade disease, $\square$ high-grade disease, and $\mathbf{a}$ cervical cancer.

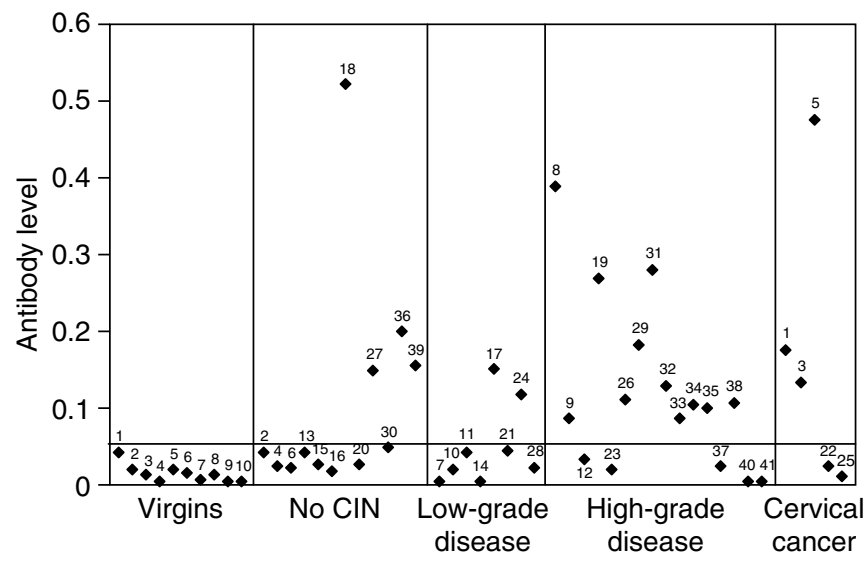

Figure 3 Relative HPVI6-specific antibody levels obtained using an ELISA that employed HPV I 6 LI -VLPs. Antibody levels were quantitated by relating the absorbencies obtained for each sample to that obtained from the positive control (Camvir I) run under standard conditions on every assay plate. The negative control providing the negative cutoff value $(-)$ was taken as 2 s.d. above the mean of the absorbencies obtained using the virgin controls. Background readings, where no antigen had been bound to the plate, were subtracted from experimental readings in every case.

However, HPV16 proteins are still being expressed in high-grade lesions (Doorbar et al, 1997) and it is likely that HPV-specific memory $\mathrm{T}$ cells are already present.

\section{Cross-reacting T-cell responses}

Given the degree of sequence homology between related HPV types, it is possible that we may have detected crossreactive responses to other genital HPVs. T-cell crossreactivity usually requires conserved blocks of sequence identity and this would be expected to restrict the number of epitopes which would be shared between virus types. Crossreaction is most likely to be a problem with L1, which is the most highly conserved of the HPV proteins tested. However, we have employed VLPs that contain typespecific epitopes to screen for L1 and L2 responses. E6 and E7 proteins only exhibit approximately $40 \%$ sequence homology between related virus types, and E4 sequences are highly typespecific. The problem of crossreaction has been thoroughly investigated in our recent study using HPV1 (Steele et al, 2002), and we believe that the responses obtained here are HPV16specific. If the problem of crossreaction with the common cutaneous virus types existed, this would have been observed among the negative control group.

\section{Seropositivity is related to positive T-cell reactivity}

In this study, antibody status did seem to be a good predictor of Tcell reactivity, since 18 out of the 20 samples with positive serology gave a T-cell response, and only three out of nine patients who demonstrated no T-cell reactivity had antibodies. The converse, however, was not true since out of the 32 patients who responded in the ELISPOT, only 18 were seropositive. It is difficult to draw conclusions about those patients who were seronegative due to the lag phase of several months between infection with the virus and the appearance of antibodies in the blood (Carter et al 2000), and the fact that antibody levels eventually diminish. Thus, negative serology does not mean that the individual has never been infected or is unlikely to possess HPV16-specific memory T cells.

We found that the patients who demonstrated T-cell responses of multiple specificities (patients 6, 11, 12, and 13) were 
seronegative, whereas those showing far fewer T-cell reactivities had the highest antibody titres (patients 5, 8, 18, 18 and 31). One explanation for these results is that the antibody response is slower than the T-cell response. Perhaps, the women showing multiple Tcell reactivities have only recently encountered the virus, and have large numbers of effector $\mathrm{T}$ cells, but the antibody response is not yet established. Conversely, in the other group of women with low T-cell reactivity and high antibody titres, the primary effector Tcell response may have subsided, but the serological response is still present and helping to prevent re-infection. It is difficult to define precisely the relationship between $\mathrm{T}$-cell reactivity and antibody status; more knowledge is required about the relative timescales and roles of the T- and B-cell responses to HPV during natural infection.

In summary, we have shown that ELISPOT assays of IFN- $\gamma$ release are capable of revealing T-cell reactivities to HPV16 antigens in women with cervical dysplasia and can be used to establish the spectrum of T-cell responses induced during natural infection. The ELISPOT assay is becoming established as a good method for charting HPV-specific immunity, both during natural infection and following vaccination (van der Burg et al, 2001; de Jong et al, 2002, 2004; Steele et al, 2002; Baldwin et al, 2003; Welters et al, 2003; Smith et al, 2004; Smyth et al, 2004). Setting the vaccination studies aside, there are differences between the conclusions drawn from the studies looking at natural immunity and those obtained in this study. There are several possible explanations for this. Firstly, we have examined responses directly ex vivo, which is more likely to be representative of the in vivo situation. The majority of the other studies employed an in vitro stimulation step prior to ELISPOT analysis. Secondly, we established negative cutoff values using a valid negative control

\section{REFERENCES}

Alexander M, Salgaller ML, Sette A, Barnes WA, Rosenberg SA, Steller MA (1996) Generation of tumor-specific cytolytic $\mathrm{T}$ lymphocytes from peripheral blood of cervical cancer patients by in vitro stimulation with a synthetic human papillomavirus type 16 E7 epitope. Am J Obstet Gynecol 175: 1586-1593

Altmann A, Jochmus-Kudielka I, Rainer F, Gausepohl H, Moebius U, Gissmann L, Meuer SC (1992) Definition of immunogenic determinants of the human papillomavirus type 16 nucleoprotein E7. Eur J Cancer 28: $326-333$

Baldwin PJ, van der Burg SH, Boswell CM, Offringa R, Hickling JK, Dobson J, Roberts JS, Latimer JA, Moseley RP, Coleman N, Stanley MA, Sterling JC (2003) Vaccinia-expressed human papillomavirus 16 and 18 e6 and e7 as a therapeutic vaccination for vulval and vaginal intraepithelial neoplasia. Clin Cancer Res 9: 5205-5213

Bontkes HJ, de Gruijl TD, Bijl A, Verheijen RH, Meijer CJ, Scheper RJ, Stern PL, Burns JE, Maitland NJ, Walboomers JM (1999) Human papillomavirus type 16 E2-specific T-helper lymphocyte responses in patients with cervical intraepithelial neoplasia. J Gen Virol 80: $2453-2459$

Bontkes HJ, de Gruijl TD, van den Muysenberg AJ, Verheijen RH, Stukart MJ, Meijer CJ, Scheper RJ, Stacey SN, Duggan-Keen MF, Stern PL, Man S, Borysiewicz LK, Walboomers JM (2000) Human papillomavirus type 16 E6/E7-specific cytotoxic T lymphocytes in women with cervical neoplasia. Int J Cancer 88: $92-98$

Borysiewicz LK, Fiander A, Nimako M, Man S, Wilkinson GWG, Westmorland D, Evans AS, Adams M, Stacey SM, Boursnell ME, Rutherford E, Hickling JK, Inglis SC (1996) A recombinant vaccinia virus encoding human papillomavirus types 16 and 18, E6 and E7 proteins as immunotherapy for cervical cancer. Lancet 347: 1523-1527

Bosch FX, Manos MM, Munoz M, Sherman M, Jansen AM, Peto J, Schiffman MH, Moreno V, Kurman R, Shah KV (1995) Prevalence of human papillomavirus in cervical cancer: a worldwide perspective International Biological study on cervical cancer (IBSCC) study group. J Natl Cancer Inst 87: 796-802

Boyle P (1997) Global burden of cancer. Lancet 349(Suppl 12): SII23 - SII26 group that obviously minimises the problems associated with nonspecificity. Thirdly, many of the published studies have concentrated on HPV-specific responses in normal individuals. By looking at the healthy population, these studies are likely to be detecting predominantly memory T-cell reactivity, whereas we were studying women with recent or current disease, and are therefore likely to be detecting effector populations as well as memory.

The results from the current study suggest that there are differences in how viral antigens are handled by the immune system during progressive disease of the cervix. In order to define this more precisely, more noninterventional prospective studies will be required, although there are obvious ethical problems associated with this. The vast majority of women in this cohort underwent surgical excision that is likely to have an effect on HPV16 immunity, and so a prospective study would not be possible. Defining the role played by HPV16-specific T cells in the natural history of cervical disease will aid the development of immunological assays to determine the risk of CIN progression, and therefore the management of premalignant and malignant HPV-associated neoplasia.

\section{ACKNOWLEDGEMENTS}

We acknowledge Professor Alan Rickinson for his continued support. Thanks also go to Professor Margaret Stanley and Professor Martin Sapp for their kind gifts of the HPV16 baculovirus construct and the HPV16 VLPs, respectively, and the patients who took part in this study. This work was funded by Cancer Research UK (Grant no. SP1941/2303).
Carter JJ, Koutsky LA, Hughes JP, Lee SK, Kuypers J, Kiviat JN, Galloway DA (2000) Comparison of human papillomavirus types 16, 18, and 6 capsid antibody responses following incident infection. J Infect Dis 181: $1911-1919$

Chambers MA, Wei Z, Coleman N, Nash AA, Stanley MA (1994) 'Natural' presentation of human papillomavirus type $16 \mathrm{E} 7$ protein to immunocompetent mice results in antigen specific sensitisation or sustained unresponsiveness. Eur J Immunol 24: 738-745

Chirgwin KD, Feldman J, Augenbraun M, Landesman S, Minkoff H (1995) Incidence of venereal warts in human immunodeficiency virus-infected and uninfected women. J Infect Dis 172: 235-238

Chiriva-Internati M, Liu Y, Salati E, Zhou W, Wang Z, Grizzi F, Roman JJ, Lim S, Hermonat PL (2002) Effective generation of cytotoxic T lymphocytes against cervical cancer cells by adeno-associated virus/ human papillomavirus type 16 E7 antigen gene transduction into dendritic cells. Eur J Immunol 32: 30-38

Coleman N, Birley HD, Renton AM, Hanna NF, Ryait BK, Byrne M, TaylorRobinson D, Stanley M (1994) Immunological events in regressing genital warts. Am J Pathol 102: 768-774

Cubie HA, Norval M, Crawford L, Banks L, Crook T (1989) Lymphoproliferative response to fusion proteins of human papillomaviruses in patients with cervical intraepithelial neoplasia. Epidemiol Infect 103: $625-632$

Cubie HA, Plumstead M, Zhang W, de Jesus O, Duncan LA, Stanley MA (1998) Presence of antibodies to human papillomavirus virus-like particles (VLPs) in 11-13 year old schoolgirls. J Med Virol 56: 210-216 Cullen AP, Reid R, Campion M, Lorincz AT (1991) Analysis of the physical state of different human papillomavirus DNAs in intraepithelial and invasive cervical neoplasm. J Virol 65: 606-612

Davidson EJ, Brown MD, Burt DJ, Parish JL, Gaston K, Kitchener HC, Stacey SN, Stern PL (2001) Human T cell responses to HPV16 E2 generated with monocyte-derived dendritic cells. Int $J$ Cancer 94: $807-812$

de Gruijl TD, Bontkes HJ, Stukart MJ, Walboomers JM, Remmink AJ, Verheijen RH, Helmerhorst TJ, Meijer CJ, Scheper RJ (1996a) T-cell 
proliferative responses against human papillomavirus type 16 E7 oncoprotein are most prominent in cervical intraepithelial neoplasia patients with a persistent viral infection. J Gen Virol 77: 2183-2191

de Gruijl TD, Bontkes HJ, Wallboomers JMM, Coursaget P, Stukart MJ, Dupuy C, Keuter E, Verheijen RH, Helmerhorst TJ, Duggan-Keen MF, Stern PL, Meijer CJ, Scheper RJ (1999) Immune responses against human papillomavirus (HPV) type 16 virus-like particles in a cohort study of women with cervical intraepithelial neoplasia: 1 . Differential T-helper and IgG responses in relation to HPV infection and disease outcome. J Gen Virol 80: 399-408

de Gruijl TD, Bontkes HJ, Wallboomers JMM, Stukart MJ, Doekhie FS, Remmink AJ, Helmerhorst TJ, Verheijen RH, Duggan-Keen MF, Stern PL, Meijer CJ, Scheper RJ (1998) Differential T helper cell responses to human papillomavirus type $16 \mathrm{E} 7$ related to viral clearance or persistence in patients with cervical neoplasia: a longitudinal study. Cancer Res 58: $1700-1706$

de Gruijl TD, Bontkes HJ, Wallboomers JMM, Stukart MJ, Robbesom AA, von Blomberg JT, van der Flier BM, Herbrink P, Remmink AJ, Verheijen RH, Helmerhorst TJ, Meijer CJ, Scheper RJ (1996b) Analysis of IgG reactivity against human papillomavirus type 16 E7 in patients with cervical intraepithelial neoplasia indicates an association with clearance of viral infection: results of a prospective study. Int J Cancer 68: $731-738$

de Jong A, van der Burg SH, Kwappenberg KM, van der Hulst JM, Franken KL, Geluk A, van Meijgaarden KE, Drijfhout JW, Kenter G, Vermeij P, Melief CJ, Offringa R (2002) Frequent detection of human papillomavirus 16 E2-specific T-helper immunity in healthy subjects. Cancer Res 62: $472-479$

de Jong A, van Poelgeest MIE, van der Hulst JM, Drijfhout JW, Fleuren GJ, Melief CJM, Kenter G, Offringa R, van der Burg SH (2004) Human papillomavirus type 16-positive cervical cancer is associated with impaired CD4+ $\mathrm{T}$ cell immunity against early antigens E2 and E6. Cancer Res 64: 5449-5455

Doorbar J, Foo C, Coleman N, Medcalf L, Hartley O, Prospero T, Napthine S, Sterling J, Winter G, Griffin H (1997) Characterization of events during the late stages of HPV16 infection in vivo using high-affinity synthetic Fabs to E4. Virology 238: 40-52

Evander M, Edlund K, Gustafsson A, Jonsson M, Karlsson R, Rylander E, Wadell G (1995) Human papillomavirus infection is transient in young women: a population-based cohort study. J Infect Dis 171: 1026-1031

Evans CA, Bauer S, Grubert T, Brucker C, Baur S, Heek K, Wagner H, Lipford GB (1996) HLA-A2-restricted peripheral blood cytolytic T lymphocyte response to HPV type 16 proteins E6 and E7 from patients with neoplastic cervical lesions. Cancer Immunol Immunother 42: $151-160$

Evans EM, Man S, Evans AS, Borysiewicz LK (1997) Infiltration of cervical cancer tissue with human papillomavirus-specific cytotoxic T lymphocytes. Cancer Res 57: 2943-2950

Fennema JSA, Van Ameijden EJC, Coutinho RA, Van den Hock AJAR (1995) HIV, sexually transmitted diseases and gynaecologic disorders in women: increased risk for genital herpes and warts among HIV-infected prostitutes in Amsterdam. AIDS 9: 1071-1078

Fruchter RG, Maiman M, Arrastia CD, Matthews R, Gates EJ, Holcomb K (1998) Is HIV infection a risk factor for advanced cervical cancer? J Acquir Immune Defic Syndr Hum Retrovirol 18: 241 -245

Gill DK, Bible JM, Biswas C, Kell B, Best JM, Punchard NA, Cason J (1998) Proliferative T-cell responses to human papillomavirus type 16 E5 are decreased amongst women with high grade neoplasia. J Gen Virol 77: $1971-1976$

Herrero R, Hildesheim A, Bratti C, Sherman ME, Hutchinson M, Morales J, Balmaceda I, Greenberg MD, Alfaro M, Burk RD, Wacholder S, Plummer M, Schiffman M (2000) Population-based study of human papillomavirus infection and cervical neoplasia in rural Costa Rica. J Natl Cancer Inst 92: $464-474$

Ho GY, Bierman R, Beardsley J, Chang CJ, Burk RK (1998) Natural history of cervicovaginal papillomavirus infection in young women. $N$ Engl $J$ Med 338: $423-428$

Hopfl R, Heim K, Christensen N, Zumbach K, Wieland U, Volgger B, Widschwendter A, Haimbuchner S, Muller-Holzner E, Pawlita M, Pfister H, Fritsch P (2000) Spontaneous regression of CIN and delayed-type hypersensitivity to HPV16 oncoprotein E7. Lancet 356: 1985-1986

Iwatsuki K, Tagami M, Takigawa M, Yamada M (1986) Plane warts under spontaneous regression. Immunopathologic study on cellular constituents leading to an inflammatory reaction. Arch Dermatol 122: $655-659$
Jochmus I, Osen W, Altmann A, Buck G, Hofmann B, Schneider A, Gissmann L, Rammensee HG (1997) Specificity of human cytotoxic T lymphocytes induced by a human papillomavirus type 16 E7-derived peptide. J Gen Virol 78: 1689-1695

Kadish AS, Ho GY, Burk RD, Wang Y, Romney SL, Ledwidge R, Angeletti RH (1997) Lymphoproliferative responses to human papillomavirus (HPV) type 16 proteins E6 and E7: outcome of HPV infection and associated neoplasia. J Natl Canc Inst 89: 1285-1293

Kadish AS, Romney SL, Ledwidge R, Tindle R, Fernando GJ, Zee SY, Van Ranst MA, Burk RD (1994) Cell-mediated immune responses to E7 peptides of human papillomavirus (HPV) type 16 are dependent on the HPV type infecting the cervix whereas serological reactivity is not typespecific. J Gen Virol 75: 2277-2284

Kadish AS, Timmins P, Wang Y, Ho GY, Burk RD, Ketz J, He W, Romney SL, Johnson A, Angeletti R, Abadi M (2002) Regression of cervical intraepithelial neoplasia and loss of human papillomavirus (HPV) infection is associated with cell-mediated immune responses to an HPV type E7 peptide. Cancer Epidemiol Biomarkers Prev 11: 483-488

Konya J, Eklund C, af Geijersstam V, Yuan F, Stuber G, Dillner J (1997) Identification of a cytotoxic $\mathrm{T}$ lymphocyte epitope in the human papillomavirus type 16 E2 protein. J Gen Virol 78: 2615-2620

Landis SH, Murray T, Bolden S, Wingo PA (1998) Cancer Statistics CA. Cancer J Clin 48: 6-29

Liu Y, Chiriva-Internati M, Grizzi F, Salati E, Roman JJ, Lim S, Hermonat PL (2001) Rapid induction of cytotoxic T cell responses against cervical cancer cells by human papillomavirus type 16 E6 antigen gene delivery into human dendritic cells by an adeno-associated virus vector. Cancer Gene Ther 12: 948 - 957

Luxton JC, Rose RC, Coletart T, Wilson P, Shepherd PS (1997) Serological and T-helper cell responses to human papillomavirus type $16 \mathrm{~L} 1$ in women with cervical dysplasia or cervical carcinoma and in healthy controls. J Gen Virol 78: 917-923

Luxton JC, Rowe AJ, Cridland JC, Coletart T, Wilson P, Shepherd PS (1996) Proliferative T-cell responses to the human papillomavirus type 16 E7 protein in women with cervical dysplasia and cervical carcinoma and in healthy individuals. J Gen Virol 77: 1585-1593

Murakami M, Gurski KJ, Marincola FM, Ackland J, Steller MA (1999) Induction of specific CD8+ T-lymphocyte responses using a human papillomavirus 16 E6/E7 fusion protein and autologous dendritic cells. Cancer Res 59: 1184-1187

Nakagawa M, Stites DP, Farhat S, Judd A, Moscicki AB, Canchola AJ, Hilton JF, Palefsky JM (1996) T cell proliferative response to human papillomavirus type 16 peptides: relationship to cervical intraepithelial neoplasia. Clin Diagn Lab Immunol 3: 205-210

Nakagawa M, Stites DP, Farhat S, Sisler JR, Kong MBF, Moscicki AB, Palefsky JM (1997) Cytotoxic T lymphocyte responses to E6 and E7 proteins of human papillomavirus type 16: relationship to cervical intraepithelial neoplasia. J Infect Dis 175: 927-931

Nakagawa M, Stites DP, Palefsky JM, Kneass Z, Moscicki AB (2002) CD4positive and CD8-positive cytotoxic T lymphocytes contribute to human papillomavirus type 16 E6 and E7 responses. Clin Diagn Lab Immunol 6: $494-498$

Nakagawa M, Stites DP, Patel S, Farhat S, Scott M, Hills NK, Palefsky JM, Moscicki AB (2000) Persistence of human papillomavirus type 16 infection is associated with lack of cytotoxic T lymphocyte response to the E6 antigens. J Infect Dis 182: 595-598

Nimako M, Fiander AN, Wilkinson GWG, Borysiewicz LK, Man S (1997) Human papillomavirus-specific cytotoxic T lymphocytes in patients with cervical intraepithelial neoplasia grade III. Cancer Res 57: $4855-4861$

Palefsky JM, Minkoff H, Kalish LA, Levine A, Sacks HS, Garcia P, Young M, Melnick S, Miotti P, Burk R (1999) Cervicovaginal human papillomavirus infection in human immunodeficiency virus-1 (HIV)-positive and high risk HIV-negative women. $J$ Natl Cancer Inst 91: 226-236

Ressing ME, Van Driel WJ, Celis E, Sette A, Brandt RMP, Hartman M, Anholts JDH, Schreuder GMT, Ter Harmsel WB, Fleuren GR (1996) Occasional memory cytotoxic T-cell responses of patients with human papillomavirus type 16-positive cervical lesions against a human leukocyte antigen- $\mathrm{A}^{\star} 0201$ restricted E7-encoded epitope. Cancer Res 56: $582-588$

Schoell WM, Mirhashemi R, Liu B, Janicek MF, Podack ER, Penalver MA, Averette HE (1999) Generation of tumour-specific cytotoxic T lymphocytes by stimulation with HPV type 16 E7 peptide-pulsed dendritic cells: an approach to immunotherapy of cervical cancer. Gynecol Oncol 74: $448-455$ 
Sellors JW, Karwalajtys TL, Kaczorowski J, Mahony JB, Lytwyn A, Chong S, Sparrow J, Lorincz A (2003) Incidence, clearance and predictors of human papillomavirus infection in women. Can Med Assoc J 168: $421-425$

Shepherd PS, Rowe AJ, Cridland JC, Coletart T, Wilson P, Luxton JC (1996) Proliferative $\mathrm{T}$ cell responses to human papillomavirus type $16 \mathrm{~L} 1$ peptides in patients with cervical dysplasia. J Gen Virol 77: 593-602

Smith KL, Tristram A, Gallagher KM, Fiander AN, Man S (2004) Epitope specificity and longevity of a vaccine-induced human $\mathrm{T}$ cell response against HPV18. Int Immunol 17: $167-176$

Smyth LJ, van Poelgeest MI, Davidson EJ, Kwappenberg KM, Burt Sehr P, Pawlita M, Man S, Hickling JK, Fiander AN, Tristram A, Kitchener HC, Offringa R, Stern PL, van der Burg SH (2004) Immunological responses in women with human papillomavirus type 16 (HPV-16)-associated anogenital intraepithelial neoplasia induced by heterologous primeboost HPV-16 oncogene vaccination. Clin Cancer Res 10: 2954-2961

Steele JC, Roberts S, Rookes SM, Gallimore PH (2002) Detection of $\mathrm{CD} 4+$ and $\mathrm{CD} 8+\mathrm{T}$-cell responses to human papillomavirus type 1 antigens expressed at various stages of the virus life cycle by using an enzyme-linked immunospot assay of gamma interferon release. J Virol 76: $6027-6036$

Strang G, Hickling JK, McIndoe GA, Howland K, Wilkinson D, Ikeda H, Rothbard JB (1990) Human T-cell responses to human papillomavirus type $16 \mathrm{~L} 1$ and E6 synthetic peptides: identification of T-cell determinants, HLA-DR restriction and virus type specificity. J Gen Virol 71: $423-431$

Thornberg C, Boczkowski D, Gilboa E, Nair SK (2000) Induction of cytotoxic $\mathrm{T}$ lymphocytes with dendritic cells transfected with human papillomavirus E6 and E7 RNA: implications for cervical cancer immunotherapy. J Immunother 23: 412-418

Tsukui T, Hildesheim A, Schiffman MH, Luci III J, , Contois D, Lawler P, Rush BB, Lorincz AT, Corrigan A, Burk RD, Qu W, Marshall MA, Mann D, Carrington M, Clerici M, Shearer GM, Carbone DP, Scott DR, Houghten RA, Berzofsky JA (1996) Interleukin 2 production in vitro by peripheral lymphocytes in response to human papillomavirusderived peptides: correlation with cervical pathology. Cancer Res 56: $3967-3974$

Valdespino V, Gorodezky C, Ortiz V, Kaufmann AM, Roman-Basaure E, Vazquez A, Berumen J (2005) HPV16-specific cytotoxic T lymphocyte responses are detected in all HPV16-positive cervical cancer patients. Gynecol Oncol 96: $92-102$

van der Burg SH, Ressing ME, Kwappenberg KMC, de Jong A, Straathof K, de Jong J, Geluk A, van Meijgaarden KE, Franken KLMC, Ottenhof THM, Fleuren GJ, Kenter G, Melief CJ, Offringa R (2001) Natural T-helper immunity against human papillomavirus type 16 (HPV16) E7-derived peptide epitopes in patients with HPV16-positive cervical lesions: identification of 3 human leukocyte antigen class II-restricted epitopes. Int $J$ Cancer 91: $612-618$

Walboomers JMM, Jacobs MV, Manos MM, Bosch FX, Kummer JA, Shah KV, Snijders PJF, Peto J, Meijer CJLM, Munoz N (1999) Human papillomavirus is a necessary cause of invasive cervical cancer worldwide. J Pathol 189: 12 - 19

Welters MJP, de Jong A, van den Eeden SJF, van der Hulst JM, Kwappenberg KMC, Hassane S, Franken KSH, Drijfhout JW, Fleuren GJ, Kenter G, Melief CJ, Offringa R, van der Burg SH (2003) Frequent display of human papillomavirus type 16 E6-specific memory T-helper cells in the healthy population as witness of previous viral encounter. Cancer Res 63: 636-641

Woodman CBJ, Collins S, Winter H, Bailey A, Ellis J, Prior P, Yates M, Rollason TP, Young LS (2001) Natural history of cervical human papillomavirus infection in young women: a longitudinal study. Lancet 357: $1831-1836$

Youde SJ, Dunbar PR, Evans EM, Fiander AN, Borysiewicz LK, Cerundolo V, Man S (2000) Use of fluorogenic histocompatability leukocyte antigen- $A^{\star} 201 /$ HPV16 E7 peptide complexes to isolate rare human cytotoxic T-lymphocyte-recognising endogenous human papillomavirus antigens. Cancer Res 60: 365-371 